Article

\title{
Irrigation Analysis Based on Long-Term Weather Data
}

\author{
James R. Mahan * and Robert J. Lascano \\ Cropping Systems Research Laboratory, USDA-ARS, 3810 4th Street, Lubbock, TX 79415, USA; \\ Robert.Lascano@ars.usda.gov \\ * Correspondence: James.Mahan@ars.usda.gov; Tel.: +1-806-723-5221 \\ Academic Editor: Mohammad Valipour
}

Received: 11 July 2016; Accepted: 22 August 2016; Published: 31 August 2016

\begin{abstract}
Irrigation management is based upon delivery of water to a crop in the correct amount and time, and the crop's water need is determined by calculating evapotranspiration (ET) using weather data. In 1994, an ET-network was established in the Texas High Plains to manage irrigation on a regional scale. Though producers used the ET-network, by 2010 public access was discontinued. Why did producers allow a valuable irrigation-management tool to be eliminated? Our objective was to analyze the effect of declining well capacities on the usefulness of cotton ET $\left(\mathrm{ET}_{\mathrm{c}}\right)$ for irrigation. Thirty years (1975-2004) of daily $\mathrm{ET}_{\mathrm{C}}$ data were used to compare irrigation demand vs. irrigation responses at four locations, analyzed for multiple years and range of well capacities for three irrigation-intervals. Results indicated that when well capacities declined to the point that over-irrigation was not possible, the lower well capacities reduced the value of $\mathrm{ET}_{\mathrm{c}}$ in terms of the number of irrigations and total amount of water applied. At well capacities $<1514 \mathrm{~L} \cdot \mathrm{min}^{-1}$ the fraction of irrigations for which $\mathrm{ET}_{\mathrm{c}}$ information was used to determine the irrigation amount was $<35 \%$ across years and irrigation intervals. The value of an $\mathrm{ET}_{\mathrm{C}}$-based irrigation may fall into disuse when irrigation-water supplies decline.
\end{abstract}

Keywords: cotton; irrigation scheduling; evapotranspiration; well-capacity; weather-network; water management

\section{Introduction}

The 1930's drought that afflicted the Great Plains of the USA motivated the USDA in 1935 to start a weather forecasting program at Michigan Institute of Technology that became the foundation for the monthly weather forecasts distributed by the US Weather Bureau [1]. Furthermore, the drought compelled agricultural producers to irrigate crops, and questions of how much water and when to apply, i.e., irrigation scheduling, were asked. Attempts to answer these questions using weather networks were initially developed at the University of Nebraska in the early 1980's [2]. Since then, the number of weather networks providing evapotranspiration (ET) estimates increased across North America. A survey in 1991 revealed 831 weather stations in USA and Canada [3], and in 1999, the number of weather stations had increased by $45 \%$ to 1200 [4]. Examples describing the technical aspects of the weather stations and of regional networks for different USA states are given for California [5], Ohio [6,7], Georgia [8], Oklahoma [9], Texas [10], and Washington [11]. This approach has also been used in other countries, e.g., Kenya [12], Australia [13], and Spain [14]. This is by no means an exhaustive list, and our purpose is to illustrate the proliferation and adoption of weather-generated information to provide estimates of the water requirements of crops. Our attention will focus on the current situation in the Texas High Plains (THP) in terms of the supply of irrigation water and adoption of the information generated by weather stations and used to determine estimates of crop ET. 
In Texas, the history of irrigation is well documented [15,16]. It is known that in circa 1540, Native Americans had established irrigation systems near El Paso and Pecos, TX, USA, using water from the Rio Grande and Pecos River. Over a 28-year span, from 1716 to 1744, Franciscans were the first Europeans to irrigate crops using "acequias" (irrigation canals) in Catholic missions near San Antonio [17]. In Texas, corn (Zea mays L.) was the first field crop to be irrigated by both Native Americans and missionaries [16]. In the THP, large-scale irrigation started in 1920 and due to the scarcity of surface water, agricultural producers were forced to withdraw the groundwater, first with windmills and thereafter with irrigation pumps [18]. However, irrigation only became practical in the 1920-1930s with the development of the internal combustion engine [19] and also in response to the drought of the Dust Bowl [20]. The 1960's were characterized as a decade of alarm due to the rapid decline of the ground water table [18].

The source of nearly all irrigation water in the THP is the Ogallala Aquifer [21], which is a large aquifer that covers eight states of the USA. In the THP, the Ogallala Aquifer is mostly a closed system where withdrawals exceed recharge, and over the years has resulted in a decline of the water table [19,21-23]. In some areas of the Ogallala Aquifer, this decline resulted in well capacities that produce less than the daily water requirements of crops, leading to the implementation of so-called deficit irrigation, i.e., the practice of applying less water than the water demand of the crop [24,25]. Also, and in response to this decline and to use seasonal rain, the sprinkler irrigation concept known as Low Energy Precision Application (LEPA) was developed for the THP [26-28]. This system was adapted for the declining well capacities of the THP that range from 1.3 to $>7 \mathrm{~mm} \cdot$ day $^{-1}$ of the daily water supply [29]. The well capacity often determines the amount of water that can be applied regardless of environmental demand and crop needs. In some areas of the THP, the only irrigation option is to continuously water the crop throughout the growing season, from planting to harvest [29].

The development of irrigation systems such as LEPA [26,27] and sub-surface drip [30] requires an estimate of the daily water requirement of the crop. This value may be calculated by multiplying a potential or reference ET value by a crop coefficient $\left(\mathrm{K}_{\mathrm{c}}\right)$, and this method is referred to as the "engineering approach" by [29]. This method was first suggested by [31] and is now the standard and recommended procedure for irrigation of crops worldwide [32,33]. This method to calculate ET provided a "standard" set of calculations for convenience and reproducibility for a hypothetical reference surface applied to a short and tall surface. The standardized reference evapotranspiration $\left(\mathrm{ET}_{\mathrm{sz}}\right)$ for a short crop $\left(\mathrm{ET}_{\mathrm{os}}\right)$ is a clipped and cool season grass $\left(\mathrm{ET}_{\mathrm{os}}\right)$ with a height of $0.12 \mathrm{~m}$, and for a tall crop $\left(\mathrm{ET}_{\mathrm{rs}}\right)$, is full cover alfalfa with a height of $0.5 \mathrm{~m}$ [33]. The required weather inputs to calculate crop $\mathrm{ET}_{\mathrm{sz}}$ for either a short or tall crop are the same and include short-wave irradiance, air temperature and humidity, and wind-speed, normally measured at a screen-height of $2.0 \mathrm{~m}$. An additional input is the surface soil heat flux. The availability of commercial weather stations with data-loggers able to record weather variables every second provide a range of timescales, from minutes to days, for the calculated values of crop $\mathrm{ET}_{\mathrm{sz}}$ for the entire growing season. 


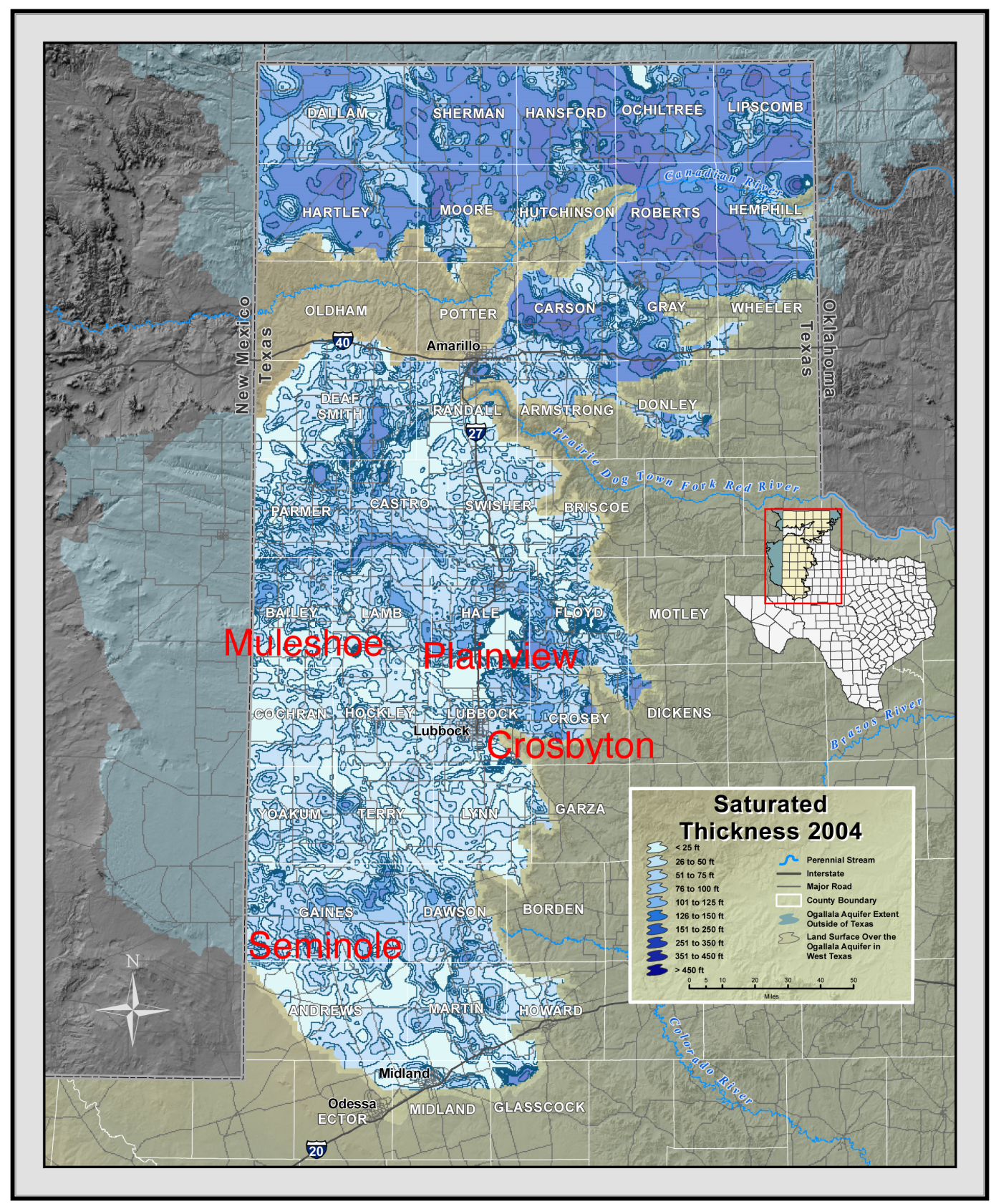

Figure 1. Location and saturated thickness of the four sites, Muleshoe (Bailey County), Seminole (Gaines County), Crosbyton (Crosby County) and Plainview (Hale County) used in our study [34].

As previously described, the availability of commercial weather stations, advances in cellular communication and the Internet led to the development of "weather networks" that provided information on crop $\mathrm{ET}_{\mathrm{sz}}$. In 1994, the Texas A\&M University Research and Extension Service started the "South Plains Potential ET Network" with weather stations at Halfway, Lubbock and Lamesa, TX. The network provided daily values of $\mathrm{ET}_{\mathrm{sz}}$ and heat units from 1 April to 31 October, and the information was delivered on a daily basis via facsimile to subscribers that paid a nominal fee for the service. In 1995, a similar weather network was established in Amarillo, TX, i.e., "Texas North Plains PET Network" with weather stations at Dalhart, Etter, Morse, Whitedeer, Bushland and Dimmit [35]. Despite this expansion in coverage across the THP, fourteen years later in 2010, due to budget cuts and lack of support, public access to the weather networks was discontinued. This led us to question why irrigators and other users of the network allowed such a valuable tool to be eliminated from 
their operations in the THP. Perhaps it was reasonable to ask whether the usefulness of the system as an irrigation management tool was less than expected. Other relevant questions included did changes in irrigation and management practices over the life of the weather network reduce its value to the end users? To what extent do the irrigation recommendations of the ET network match the irrigators' ability to act on those recommendations? While ET networks no doubt provide useful information on the magnitude and temporal pattern of ET over the course of a growing season, the extent to which such data can be considered "actionable" on the part of the irrigator is perhaps not fully understood or appreciated. Furthermore, our experience working with local producers, even those considered progressive irrigators, indicates that at least some remain unconvinced of the value and utility of the information delivered from $\mathrm{ET}_{\mathrm{sz}}$ networks.

We are not the first to question the value of weather networks to the end users as a tool for water management. The value of climate information as a decision making tool has been investigated [36-39], and the adoption of weather information has been reported [40-42]. In Texas, a survey sent to 900 agricultural producers indicated the importance of agricultural weather information, e.g., freeze warnings, precipitation probabilities, and soil temperature and water content, commonly broadcast over newspaper, TV and radio media; however, few producers were willing to pay for this information [43]. A similar conclusion was reached in Oklahoma where farmers and ranchers did not want to pay significant fees to have access to weather information beyond raw data [44]. Nevertheless, technology transfer of agricultural water management programs from weather networks via extension and outreach activities remains a high priority in Nebraska [45] and elsewhere. The occurrence of drought events remains a driver for the use and adoption of "smart" irrigation controllers based on ET [46] and in the adoption of information generated from weather networks. For example, in California, users of the California Irrigation Management Information System increased over a 5-year span (1986 to 1991) from 500 to 2000 [47].

To provide insight and to answer the previous questions, we selected and used 30-year (1975-2004) weather data sets for four locations of the THP to investigate the relationship between ET-based irrigation recommendations for cotton (Gossypium hirsutum L.) and the ability of irrigators to manage irrigation with those recommendations. While our research approach is specific to our location, climate and crop, we believe that our method has general applications to other regions and crops. Our goal was to identify options to improve the successful adoption of ET-based irrigation as a management tool [45,48]. Our purpose is not to evaluate specific advantages or disadvantages of any particular irrigation system for cotton production in the THP. Furthermore, we present a first "order solution" to address the decline in irrigation water, and we do not consider the many agronomic options that are available, e.g., capture of rain, cotton varieties, crop rotations, minimum tillage, and other practices that are in use in the THP. The increased competition for water between agriculture and urban users [49] and the continued incidence of droughts gives us renewed interest in improving tools that irrigators could use to manage water efficiently.

\section{Materials and Methods}

\subsection{Study Area and Irrigation Practices}

The study area consisted of four sites across the THP, Muleshoe (Bailey County), Seminole (Gaines County), Crosbyton (Crosby County) and Plainview (Hale County). Irrigation well capacities within the THP range from 1.3 to $7.6 \mathrm{~mm} \cdot$ day $^{-1}$ [26,29], and the saturated thickness of the Ogallala Aquifer ranges from $<15 \mathrm{~m}$ to $>180 \mathrm{~m}$ (Figure 1).

\subsection{Usefulness of an ET-Based Irrigation Management System}

One way to assess the usefulness of an ET-based irrigation management system is to measure the extent to which availability of the ET information generated by the management system influences the irrigator's decisions. Such an assessment of ET-based irrigation compares the irrigation demand 
calculated from crop ET and the irrigation response of the irrigator to that demand. Ultimately, the usefulness of any ET-based irrigation management system depends on the strength of the linkage between irrigation demand and irrigation response. Our approach was to calculate pairs of irrigation demand and irrigation response amounts over a period of years, for various irrigation systems, and to determine how the demand and response amounts were affected.

In a well-functioning irrigation management system, in the absence of limitations in irrigation water, the irrigation response would equal the irrigation demand and, as water becomes limiting, the irrigation response amounts would decrease relative to the irrigation demands. Limitations in irrigation water are typically a result of two factors: (1) well capacity, the specific quantity of water that a well will yield per unit of time, e.g., $\mathrm{L} \cdot \mathrm{min}^{-1}[50,51]$; and (2) irrigation-interval, i.e., the number of days between irrigation events. For example, in a center pivot, this is determined by the speed of the pivot. Well capacity is subject to change over time given the thickness and properties of the water-bearing strata and depth to ground water. The irrigation interval is related to several factors, e.g., irrigation method, soil type and crop.

Cotton is a perennial plant grown as an annual that is well adapted to arid climates and responds well to frequent deficit irrigation at different intervals and thus is well-suited to a variety of irrigation methods. The two main irrigation methods used in the THP are center pivots ( $400 \mathrm{~m}$ long) and subsurface drip, and for both methods, the irrigation strategies are designed to use seasonal rain and irrigation water efficiently [26-28]. We selected three time-intervals (1, 5 and 10 days) and five well capacities $\left(1.3,2.5,4.1,5.1\right.$, and $7.6 \mathrm{~mm} \cdot$ day $\left.^{-1}\right)$ associated with an irrigated area of 41 ha. Thus, the irrigation methods, irrigation intervals and well capacities represent irrigation practices common in the THP. For example, for the selected irrigation intervals, a sub-surface drip irrigation system could be operated on any of the three time-intervals, while the 5-day and 10-day are perhaps more representative of center pivot irrigation systems. The selection of an irrigation interval involves aspects of crop water use, soil characteristics and irrigation equipment. Sub-surface drip can often be implemented at 1-day intervals though under some conditions (limited water or in-season rain), extension to a 5-day interval can be advantageous in terms of enhanced root development. In center pivot systems, increasing the amount of irrigation water applied per event by increasing the irrigation interval can reduce soil water evaporation associated with such systems. In general, the trend in the THP has been towards increasing the irrigation interval. Further, a 10-day irrigation interval may be unusual, but in sandy soils, might be beneficial. A summary of the well capacity and irrigation interval used in our analysis is given in Table 1.

Table 1. Water applied for the selected three irrigation intervals and five well capacities for four sites across the Texas High Plains.

\begin{tabular}{cccc}
\hline $\begin{array}{c}\text { Irrigation Interval } \\
\text { (days) }\end{array}$ & $\begin{array}{c}\text { Well Capacity } \\
\left(\mathbf{m m} \cdot \mathbf{d a y}^{\mathbf{- 1}} \mathbf{)}\right.\end{array}$ & $\begin{array}{c}\text { Well Capacity } \\
\left(\mathbf{L} \cdot \mathbf{m i n}^{-\mathbf{1}} \mathbf{)}\right.\end{array}$ & $\begin{array}{c}\text { Maximum Water Available \# } \\
(\mathbf{m m})\end{array}$ \\
\hline & 1.3 & 370 & 1.3 \\
& 2.5 & 712 & 2.5 \\
& 4.1 & 1167 & 4.1 \\
& 5.1 & 1452 & 5.1 \\
& 7.6 & 2164 & 7.6 \\
\hline & 1.3 & 370 & 6.5 \\
5 & 2.5 & 712 & 12.5 \\
& 4.1 & 1167 & 20 \\
& 5.1 & 1452 & 25.5 \\
& 7.6 & 2164 & 38 \\
\hline & 1.3 & 370 & 13 \\
& 2.5 & 712 & 25 \\
& 4.1 & 1167 & 41 \\
& 5.1 & 1452 & 51 \\
& 7.6 & 2164 & 76 \\
\hline
\end{tabular}

* Amount of water applied to 41 ha ( 100 Acres). \# Maximum amount of irrigation water that can be applied for the given well capacity at each of the three irrigation intervals. 


\subsection{Calculation of Cotton ET (ET $)$}

We used the standardized reference equation for a short crop $\left(\mathrm{ET}_{\mathrm{os}}\right)$ [33] using as input 30 years (1975-2004) of daily weather data for Muleshoe, Seminole, Crosbyton, and Plainview (Figure 1). These daily $\mathrm{ET}_{\mathrm{os}}$ values were calculated using the Ogallala Agro-Climate Tool given by [52]. The daily reference $\mathrm{ET}_{\mathrm{os}}$ values for each location were then used to calculate corresponding daily values of cotton ET $\left(\mathrm{ET}_{\mathrm{c}}\right)$ in $\mathrm{mm} \cdot \mathrm{day}^{-1}$, as adjusted by a crop coefficient $\left(\mathrm{K}_{\mathrm{c}}\right)$ given by [32] as follows:

$$
E T_{C}=E T_{O S} \times K_{C}
$$

Daily values of $\mathrm{ET}_{\mathrm{c}}$ were calculated for a 110-day period from 15 May (Day Of Year, DOY 135) to 31 August (DOY 243) for each 30-year interval (Figure 2a). This 110-day period represents the average length of a cotton-growing season where the cotton crop would be irrigated.

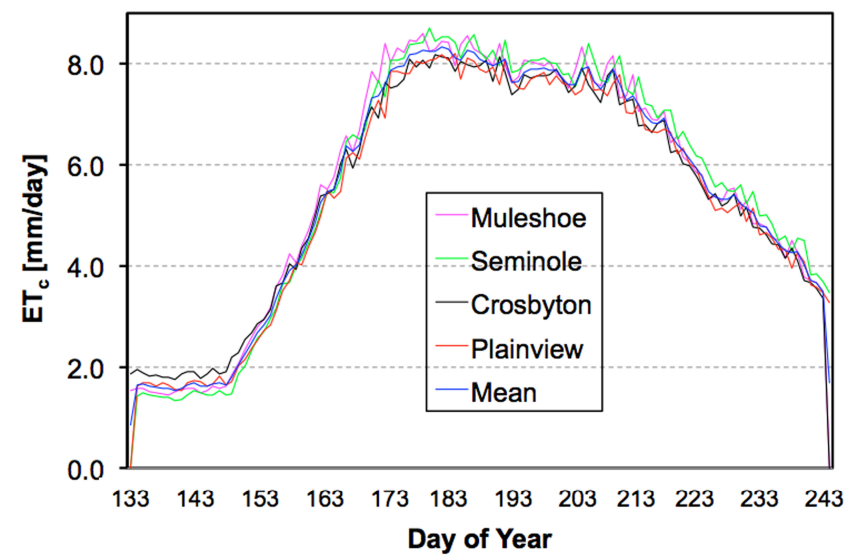

(A)

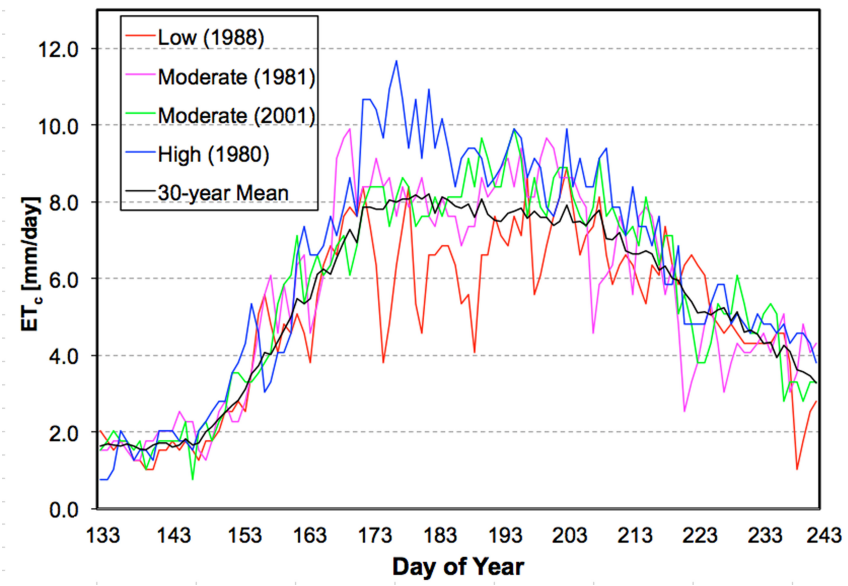

(B)

Figure 2. (A) The 30-year mean daily cotton $\mathrm{ET}\left(\mathrm{ET}_{\mathrm{c}}\right)$ for four locations across the THP over the course of a 110-day period, from DOY 135 to DOY 243; (B) Daily calculated cotton ET (ET $)$ for the year with the lowest (1988), two moderate (1981 and 2001) and highest (1998) values of $\mathrm{ET}_{\mathrm{c}}$, for Plainview, $\mathrm{TX}$, USA, for the 110-day period, from DOY 135 to DOY 243. Also shown is the 30-year average value of $\mathrm{ET}_{\mathrm{c}}$.

\subsection{Calculation of Irrigation Demand}

Irrigation demand ( $\mathrm{mm}$ of water) was calculated from the $\mathrm{ET}_{\mathrm{c}}$ values (Equation (1)) described above and by grouping $\mathrm{ET}_{\mathrm{c}}$ values into three classes: (1) 1-day sums; (2) 5-day sums; and (3) 10-day sums, resulting in 143 irrigation demand values for each year at each of the four sites over the 
30-year period. Since this procedure generated a total of 17,160 irrigation demand values, we limited our analysis to Plainview, TX, USA, where we conducted previous studies [53]. Further, using the 30-year interval at Plainview generated 4290 irrigation demand values, and we limited the analysis by segregating the data into five groups consisting of: (1) 1988, the lowest total $\mathrm{ET}_{\mathrm{c}}$ year; (2 and 3) 1981 and 2001, moderate total $\mathrm{ET}_{\mathrm{c}}$ years; (4) 1980, the highest total $\mathrm{ET}_{\mathrm{c}}$ year; and (5) the 30-year mean of $\mathrm{ET}_{\mathrm{c}}$ for the 110-day period (Figure $2 \mathrm{~b}$ ). Thereafter, and for the 110-day irrigation period, we summed the daily values of $\mathrm{ET}_{\mathrm{C}}$ for the three daily irrigation intervals (1-, 5- and 10-day) as follows:

$$
j-\text { day }=\sum_{i=1}^{1=110} E T_{c, i}
$$

where $j$ is the time interval in days, i.e., 1-day, 5-day and 10-day, and $i$ is the value of $\mathrm{ET}_{\mathrm{c}}(\mathrm{mm})$ for each day of the 110-day period. These calculations yielded 110 values for the 1-day, 22 values for the 5-day, and 11 values for the 10-day interval, for a total of 143 values of $\mathrm{ET}_{\mathrm{c}}$ for each of the five groupings for a total of 715 irrigation demand values. Each $\mathrm{ET}_{\mathrm{c}}$ value represents an irrigation demand (mm of water) based on calculated values of $\mathrm{ET}_{\mathrm{c}}$.

\subsection{Calculation of Irrigation Response}

In our analysis, irrigation demand is an irrigation goal that the irrigator may or may not be able to meet, and the irrigation response represents the amount of irrigation water $(\mathrm{mm})$ that the irrigator is able to apply in response to the demand. The assessment of the usefulness of the $\mathrm{ET}_{\mathrm{c}}$-based irrigation method involves calculating irrigation responses for each of the 715 calculated irrigation demands at each of the five well capacities. The irrigation response associated with each irrigation demand is primarily determined/limited by the amount of water that can be applied in response to the demand. For each of the 715 calculated irrigation demand values, an irrigation response amount $(\mathrm{mm})$ was calculated for each of the five well capacities that define the limits on the irrigation response (Table 1). For the three irrigation intervals and five well capacities, the following decision criteria were applied to produce irrigation demand/irrigation response pairs for possible irrigation events:

$$
\begin{aligned}
& \text { If "irrigation demand" } \leq \text { maximum irrigation, then } \\
& \text { "Irrigation response" = "irrigation demand" }
\end{aligned}
$$

and

$$
\begin{aligned}
& \text { If "irrigation demand" }>\text { maximum irrigation, then } \\
& \text { "Irrigation response" = maximum irrigation }
\end{aligned}
$$

Applying this approach of using $\mathrm{ET}_{\mathrm{C}}$ for the irrigation of a cotton crop in Plainview, over four representative years and the 30-year mean at three irrigation intervals and the five well capacities (Table 1), resulted in 3575 irrigation scenarios for analysis.

\subsection{Analysis of Irrigation Demand/Irrigation Response Pair Usefulness}

Based on the above criteria, the usefulness of an irrigation demand/irrigation response pair was assessed in terms of the extent to which the irrigator's decision was affected by the $\mathrm{ET}_{\mathrm{c}}$-based information. Two irrigation outcomes were possible, first as defined in Equation (3), when (1) irrigation demand $\leq$ maximum irrigation, the irrigator applies an irrigation that matches the irrigation demand and thus has altered irrigation in response to the $\mathrm{ET}_{\mathrm{c}}$-based value $\left(\mathrm{ET}_{\mathrm{c}}\right.$ was useful). This is defined as "variable-amount irrigation". Second, as defined in Equation (4); when (2) irrigation demand $>$ maximum irrigation, the irrigator applies an irrigation amount equal to the maximum irrigation capacity of the system, and thus the irrigation applied was not altered in response to the $\mathrm{ET}_{\mathrm{c}}$-based value $\left(\mathrm{ET}_{\mathrm{C}}\right.$ was not useful). $\mathrm{This}_{\mathrm{ET}}$-independent irrigation is defined as "maximum-amount irrigation". 
The usefulness of the $\mathrm{ET}_{\mathrm{c}}$-based approach over a season was determined by the fraction of seasonal irrigations that were variable-amount irrigations. The amount of water applied in maximum-amount irrigations is defined by well capacity instead of $\mathrm{ET}_{\mathrm{c}}$. It is proposed that the usefulness of $\mathrm{ET}_{\mathrm{c}}$-based irrigation methods declines as the fraction of variable-amount irrigations declines. Each of the 3575 irrigation demand/irrigation response pairs was categorized as a variable-amount irrigation or maximum-amount irrigation in accordance with the preceding criteria.

\section{Results and Discussion}

\subsection{Seasonal $E T_{c}$ Patterns for the 30-Year Period}

Statistical analysis of the 30-year $\mathrm{ET}_{\mathrm{c}}$ data for the four sites indicated similar values for the mean (5.5), median (6.0), standard error ( $\mathrm{SE}=0.23)$, and coefficient of variation $(\mathrm{CV}=43 \%)$ (Table 2). The mode was similar for Muleshoe and Crosbyton ( 7.9), and for Seminole and Plainview ( 1.5). The skewness was negative, about -0.5 at all four sites, indicating that the $\mathrm{ET}_{\mathrm{c}}$ data were slightly skewed left. The kurtosis was also negative, about -1.1 at all four sites, indicating a heavy-tailed distribution [54]. The Shapiro-Wilk test for normality yielded a value of 0.9 for the four sites $\left(p\right.$-value $\left.1.9 \times 10^{-7}\right)$. The similarity of these results is not surprising given that the four selected sites are within $200 \mathrm{~km}$ of each other (Figure 1), even though they delineate a large region that is irrigated in Texas [55].

Table 2. Statistical parameters of calculated daily cotton ET $\left(E_{\mathrm{c}}\right)$ values for the 30-year data set (1975-2004) for the four locations across the THP. Given are minimum, maximum, number of points per year, coefficient of variation (CV), standard error (SE), mode and median, and the moments of the mean, variance, skewness and kurtosis. The Shapiro-Wilk test for normality and corresponding $p$-value for each location are also presented.

\begin{tabular}{|c|c|c|c|c|c|c|}
\hline Statistical Parameter $\mathrm{ET}_{\mathrm{c}}$ & Moments of the Mean & Unit & Muleshoe & Seminole & Crosbyton & Plainview \\
\hline Minimum & & $\mathrm{mm} \cdot$ day $^{-1}$ & 0.0 & 0.0 & 0.0 & 0.0 \\
\hline Maximum & & $\mathrm{mm} \cdot$ day $^{-1}$ & 8.6 & 8.7 & 8.2 & 8.2 \\
\hline Points/Year & & & 110 & 110 & 110 & 110 \\
\hline $\mathrm{CV}$ & & $\%$ & 44.3 & 44.8 & 41.4 & 43.0 \\
\hline SE & & & 0.24 & 0.24 & 0.22 & 0.22 \\
\hline Mode & & $\mathrm{mm} \cdot \mathrm{day}^{-1}$ & 8.0 & 1.4 & 7.8 & 1.6 \\
\hline \multirow[t]{5}{*}{ Median } & & & 6.1 & 6.2 & 5.9 & 5.9 \\
\hline & Mean & $\mathrm{mm} \cdot \mathrm{day}^{-1}$ & 5.6 & 5.6 & 5.5 & 5.4 \\
\hline & Variance & & 6.1 & 6.3 & 5.5 & 5.4 \\
\hline & Skewness & & -0.51 & -0.55 & -0.48 & -0.49 \\
\hline & Kurtosis & & -1.09 & -1.06 & -1.1 & -1.12 \\
\hline Shapiro-Wilk & & & 0.89 & 0.89 & 0.89 & 0.89 \\
\hline$p$-value & & & $1.7 \times 10^{-7}$ & $1.2 \times 10^{-7}$ & $2.4 \times 10^{-7}$ & $2.2 \times 10^{-7}$ \\
\hline
\end{tabular}

\subsection{Role of $E T_{c}$-Based Irrigation to Prevent Over-irrigation}

A potentially significant advantage of using an $\mathrm{ET}_{\mathrm{c}}$-based irrigation scheme is the prevention of over-irrigation as compared to irrigation schemes that are based on applying predetermined periodic irrigation with a fixed amount of water, e.g., $50 \mathrm{~mm}$ every 5 days. In a typical "available amount" or "maximum-amount" scenario, an irrigator would apply the maximum amount of water that is available, i.e., well capacity, in each irrigation event. This approach is often used in regions where water is abundant and/or inexpensive as was the case in the early years of irrigation in the THP [21,22].

In a maximum-amount irrigation scenario, the amount of irrigation applied over the 110-day irrigation period, as used in this study, equals the maximum daily irrigation amount multiplied by 110 . This amount is unaffected by weather conditions and is only a function of the well capacity. For the well capacities used in this study, the seasonal maximum-amount of irrigation applied would be $143 \mathrm{~mm}$ for the $379 \mathrm{~L} \cdot \mathrm{min}^{-1}$ well capacity, $275 \mathrm{~mm}$ for the $757 \mathrm{~L} \cdot \mathrm{min}^{-1}, 451 \mathrm{~mm}$ for the $1136 \mathrm{~L} \cdot \mathrm{min}^{-1}, 561 \mathrm{~mm}$ for the $1514 \mathrm{~L} \cdot \mathrm{min}^{-1}$, and $836 \mathrm{~mm}$ for the $2270 \mathrm{~L} \cdot \mathrm{min}^{-1}$. With respect to the potential to over-irrigate, 
the amount of over-irrigation in a season at each well capacity depends on the cumulative $\mathrm{ET}_{\mathrm{c}}$ over the 110-day period and thus is related to the specific year and location. The amount of over-irrigation associated with a given seasonal $\mathrm{ET}_{\mathrm{c}}$ amount is the difference between the maximum amount and the $\mathrm{ET}_{\mathrm{C}}$ amount for the same period.

The calculated seasonal (110-day) $\mathrm{ET}_{\mathrm{c}}$ for Plainview, TX, USA, was $551 \mathrm{~mm}$ for the low $\mathrm{ET}_{\mathrm{c}}$ year (1988), 618 and $629 \mathrm{~mm}$ for the two moderate $\mathrm{ET}_{\mathrm{c}}$ years (1981 and 2001), $687 \mathrm{~mm}$ for the high $\mathrm{ET}_{\mathrm{c}}$ year (1980), and $599 \mathrm{~mm}$ for the 30-year mean. For example, the potential of over-irrigation for the $2270 \mathrm{~L} \cdot \mathrm{min}^{-1}$ well capacity would be the difference between $836 \mathrm{~mm}$ and $551 \mathrm{~mm}$, i.e., $285 \mathrm{~mm}$ for the low $\mathrm{ET}_{\mathrm{c}}$ year, $281 \mathrm{~mm}$ and $207 \mathrm{~mm}$ for the two moderate $\mathrm{ET}_{\mathrm{c}}$ years, $149 \mathrm{~mm}$ for the high $\mathrm{ET}_{\mathrm{c}}$ year, and $237 \mathrm{~mm}$ for the 30 -year $\mathrm{ET}_{\mathrm{c}}$ mean. Over-irrigation amounts for the five well capacities, over four years and the 30-year period, are shown in Figure 3. The results show that, in all years of the analysis, the potential for over-irrigation decreased as the well capacity decreased. At the lowest well capacity $\left(379 \mathrm{~L} \cdot \mathrm{min}^{-1}\right)$ it was not possible to over-irrigate, whereas for the 1-day irrigation interval at the highest well capacity $\left(2270 \mathrm{~L} \cdot \mathrm{min}^{-1}\right)$, the minimum and maximum over-irrigation amounts for the high $\mathrm{ET}_{\mathrm{c}}$ year were $270 \mathrm{~mm}$ and $345 \mathrm{~mm}$, respectively. Over-irrigation of $>300 \mathrm{~mm}$ occurred in the low $\mathrm{ET}_{\mathrm{c}}$ year regardless of irrigation frequency (Figure 3). These results indicated that a crop-based ET system provides the opportunity to reduce the amount of irrigation applied for well capacities $>1000 \mathrm{~L} \cdot \mathrm{min}^{-1}$, though the water saved declined as the total seasonal irrigation decreased. These over-irrigation outcomes represent an upper limit, as rainfall is not included in this evaluation. However, in practice, in regions with low rainfall, many irrigators with sufficient water resources often ignore in-season rain in their irrigation management strategies. In essence, irrigators will ignore the efficiency of irrigation in order to achieve the crop yield stability that is associated with excess irrigation. A maximum irrigation amount strategy is primarily an economic objective as opposed to an agronomic management decision. All else being equal, there are clear advantages to implement an $\mathrm{ET}_{\mathrm{c}}$-based irrigation when over-irrigation is a possibility and represents an obvious first step in water conservation when over-irrigation, while possible, is no longer a desired outcome.

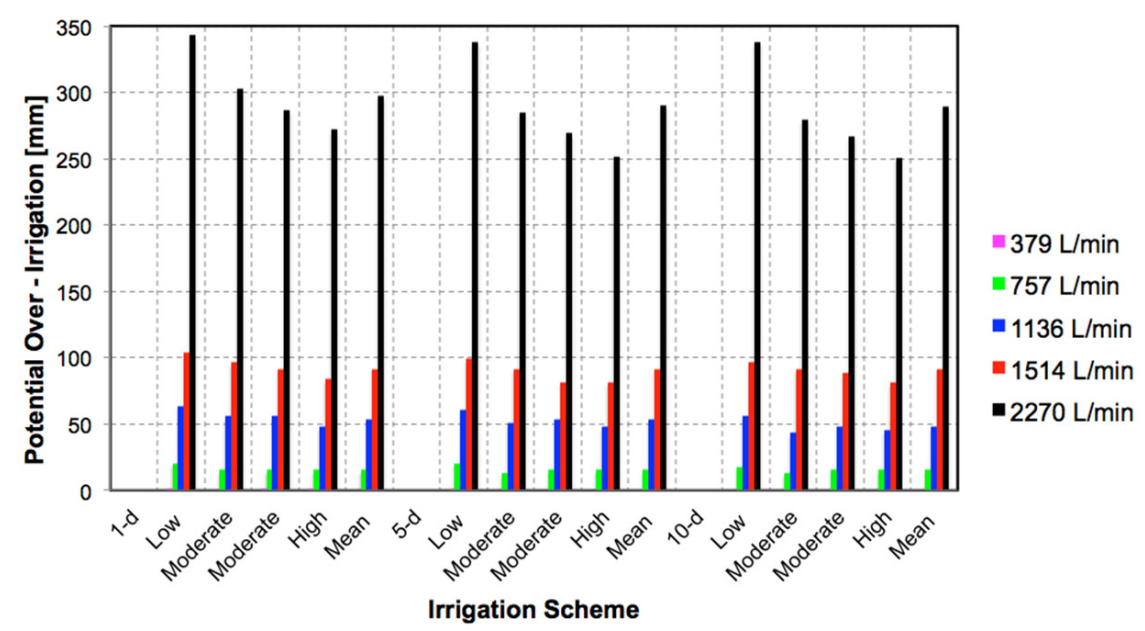

Figure 3. Potential over-irrigation amount $(\mathrm{mm})$ as a function of irrigation scheme for the 1-day, 5-day and 10-day irrigation frequencies for Plainview, TX, USA. For each irrigation frequency, the potential over-irrigation amount is plotted as a function of well capacity.

\subsection{Usefulness of $E T_{c}$-Based Irrigation in the Absence of Over-irrigation}

One goal of this study was to explain why the $\mathrm{ET}_{\mathrm{c}}$-network on the THP fell into disuse. Clearly on farms where over-irrigation is possible, but not considered a problem, adoption of an $\mathrm{ET}_{\mathrm{c}}$-based approach would not be expected, and the suspension of the region's $\mathrm{ET}_{\mathrm{c}}$-network might go unnoticed by producers. As the ability of producers in the THP to over-irrigate has largely disappeared over the past 20 years, what other factors might have contributed to a reduction in the perceived value 
of an $\mathrm{ET}_{\mathrm{c}}$-based management? The ability to tailor irrigation amounts to match variation in crop water demand is a foundational aspect of $\mathrm{ET}_{\mathrm{c}}$-based irrigation and the basis of its usefulness for producers. However, the ability to vary the irrigation response relative to the irrigation demand decreases in synchrony with declining water availability. The value of the ability to alter the irrigation response relative to $\mathrm{ET}_{\mathrm{c}}$-based irrigation demand may be characterized in terms of frequency and the total amount of water associated with its occurrence. Previously, the irrigation response was broadly categorized into variable-amount ( $\mathrm{ET}_{\mathrm{C}}$ dependent) and maximum-amount $\left(\mathrm{ET}_{\mathrm{C}}\right.$ independent) irrigations with the usefulness of using $\mathrm{ET}_{\mathrm{c}}$ decreasing as the fraction of maximum-amount irrigations increased.

\subsection{Frequency of Variable-Amount Irrigations Events}

The variable-amount irrigation events as a function of well capacity and the five irrigation schemes are shown in Figure 4. The fraction of variable-amount irrigation events was influenced by well capacity and less so by years and irrigation intervals. For the lowest well capacity $\left(379 \mathrm{~L} \cdot \mathrm{min}^{-1}\right)$, the percent of variable-amount irrigation events was low and varied between 0 and $3 \%$ for all irrigation schemes. For the highest well capacity $\left(2270 \mathrm{~L} \cdot \mathrm{min}^{-1}\right)$, the percent of variable-amount irrigation events was higher, with $100 \%$ of irrigation events categorized as variable-amount irrigations for the low $\mathrm{ET}_{\mathrm{c}}$ year (1988) and the 30-year $\mathrm{ET}_{\mathrm{c}}$ average for the 5-day and 10-day irrigation intervals. In general, for all the irrigation intervals and well capacities, variable-amount irrigations were $<20 \%$ for the two lowest well capacities ( 379 and $757 \mathrm{~L} \cdot \mathrm{min}^{-1}$ ). Variable-amount irrigation events were generally between $30 \%$ and $45 \%$ for the $1136 \mathrm{~L} \cdot \mathrm{min}^{-1}$ and $1514 \mathrm{~L} \cdot \mathrm{min}^{-1}$ well capacities. At the highest well capacity $\left(2270 \mathrm{~L} \cdot \mathrm{min}^{-1}\right)$, variable-amount irrigation events ranged from $58 \%$ to $100 \%$. The results showed that as well capacities declined, as they have on the THP, the irrigator's ability to alter irrigation amounts in response to $\mathrm{ET}_{\mathrm{C}}$ information declines. Regardless of the year or irrigation interval, when well capacity $<1514 \mathrm{~L} \cdot \mathrm{min}^{-1}$, the fraction of irrigations that can be modified by $\mathrm{ET}_{\mathrm{c}}$ information is $<50 \%$. As the well capacity further declines, the usefulness of the $\mathrm{ET}_{\mathrm{c}}$ information provided by the network commensurately also declines. How an irrigator responds to this decline in actionable information is unknown, but it possibly contributes to a reduction in the perceived value of the weather network.

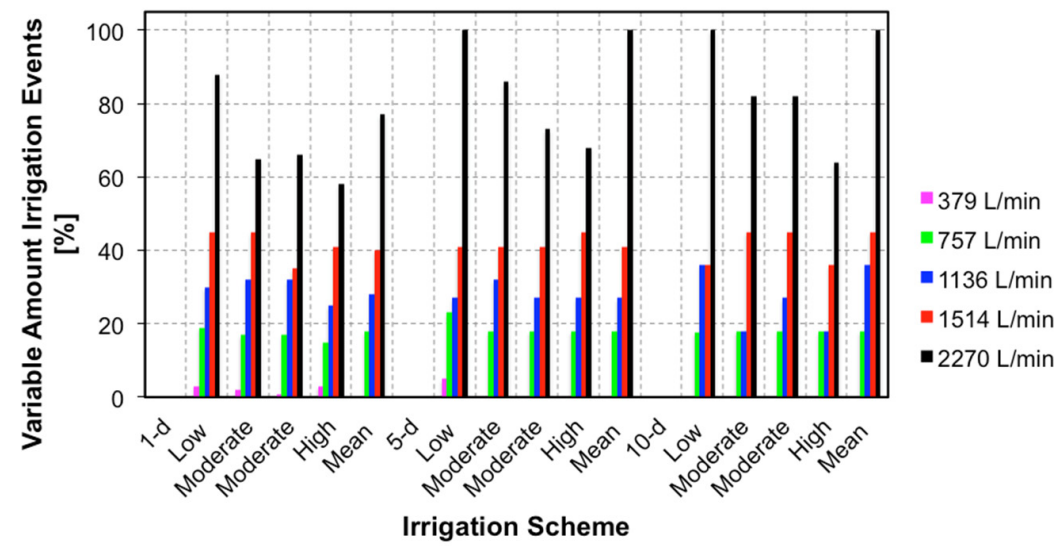

Figure 4. Variable-amount irrigation events (\%) as a function of irrigation scheme for the 1-day, 5-day and 10-day irrigation frequency for Plainview, TX, USA. For each irrigation frequency, the variable-amount irrigation events are plotted as a function of well capacity.

\subsection{Amounts of Water Associated with Variable-Amount Irrigations}

While the fraction of variable-amount irrigations declined with declining well capacity, the amount of water associated with those irrigations also declined. While the fraction of useful $\mathrm{ET}_{\mathrm{c}}$ measurements might be $50 \%$, the amount of water involved may decline to the point that it becomes unimportant from the irrigator's point of view. The seasonal amount of water applied when the calculated value of 
$\mathrm{ET}_{\mathrm{C}}$ resulted in applications not limited by the well capacity, i.e., variable-amount irrigation, is shown in Figure 5. These examples illustrate situations where the use of calculated values of $\mathrm{ET}_{\mathrm{c}}$ resulted in water savings as compared to simply irrigating at the maximum-amount (well capacity). Figure 5 shows the seasonal irrigation applied in variable-amount irrigations for all irrigation schemes and well capacities. As expected, the amounts of water applied in variable-amount irrigations were: $<6 \mathrm{~mm}$ at $379 \mathrm{~L} \cdot \mathrm{min}^{-1},<44 \mathrm{~mm}$ at $757 \mathrm{~L} \cdot \mathrm{min}^{-1},<112 \mathrm{~mm}$ at $1136 \mathrm{~L} \cdot \mathrm{min}^{-1},<164 \mathrm{~mm}$ at $1514 \mathrm{~L} \cdot \mathrm{min}^{-1}$ and $<598 \mathrm{~mm}$ at $2270 \mathrm{~L} \cdot \mathrm{min}^{-1}$ (Figure 5). Thus, the total amount of water that was "saved" using the $\mathrm{ET}_{\mathrm{c}}$ method declined with declines in well capacity, perhaps further diminishing the perceived value of $\mathrm{ET}_{\mathrm{C}}$.

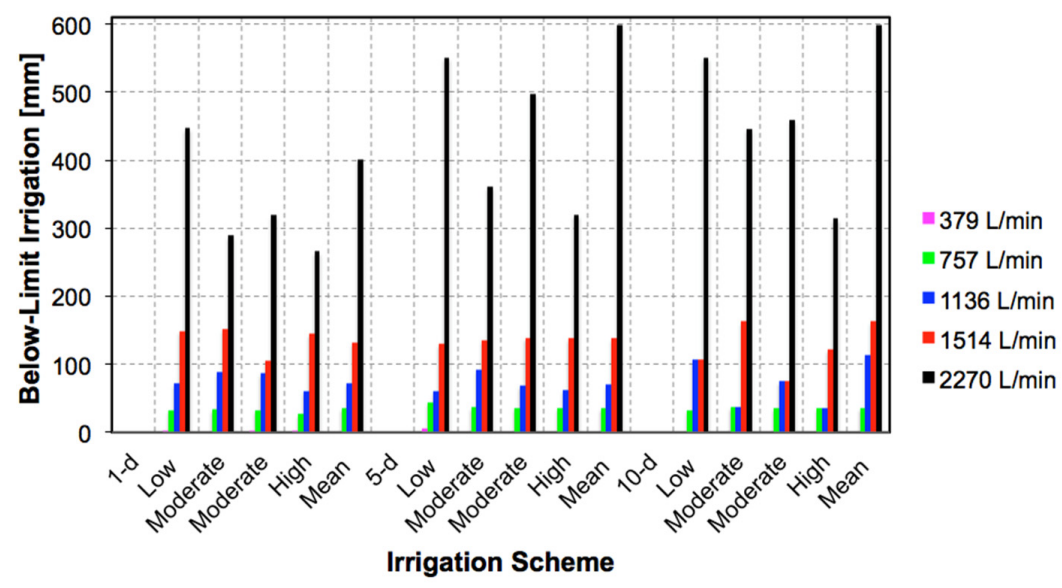

Figure 5. Below-limit irrigation amount $(\mathrm{mm})$ as a function of the irrigation scheme for the 1-day, 5-day, and 10-day irrigation frequencies for Plainview, TX, USA. For each irrigation frequency, the below-limit irrigation amounts are plotted as a function of well capacity.

\subsection{Reduced Usefulness of $E T_{c}$-Based Irrigation at Low Well Capacities}

As the irrigation capacity declined, the potential for over-irrigation decreased, and the usefulness of an $\mathrm{ET}_{\mathrm{C}}$-based approach for the prevention of over-irrigation is limited. In the absence of over-irrigation, the primary value of an $\mathrm{ET}_{\mathrm{c}}$-based system lies in the extent to which it allows the irrigator to match the irrigation response (amount applied) to variation in the irrigation demand (ET $\mathrm{C}_{\mathrm{c}}$ amount). These results demonstrated that in the THP, as well capacities decline below $2270 \mathrm{~L} \cdot \mathrm{min}^{-1}$ the usefulness of an $\mathrm{ET}_{\mathrm{C}}$-based irrigation management is diminished from the irrigator's point of view. Based on these results, at well capacities $\leq 1514 \mathrm{~L} \cdot \mathrm{min}^{-1}$, the fraction of variable-amount irrigation events (Figure 4) and the amount of water associated with such irrigations (Figure 5) declined both in absolute and in relative terms. At the lower well capacities, the irrigation strategy often becomes one in which the goal is to apply the maximum amount of water possible at the shortest interval allowed by the irrigation system $[29,53]$. Under these conditions, the relevance of scheduling irrigation based on $\mathrm{ET}_{\mathrm{C}}$ declines.

In the THP, the producer's lack of interest in $\mathrm{ET}_{\mathrm{c}}$ information provided by the ET network from 1994 to 2010 might be partially explained by the declining well capacities. Furthermore, surveys have indicated that agricultural producers in Texas and Oklahoma are not willing to pay for weather information beyond raw data $[43,44]$, and these are factors that contribute to the challenges in maintaining an operational ET network that producers may use for water management.

\subsection{Value of Historic vs. Real-Time $E T_{\mathcal{c}}$ Values in Irrigation Management}

In the THP, the apparent decline in the usefulness of using $\mathrm{ET}_{\mathrm{c}}$-based irrigation management for many, but not all, producers, raises the question, "to what extent can historic long-term values of $\mathrm{ET}_{\mathrm{C}}$ be used in place of real-time $\mathrm{ET}_{\mathrm{c}}$ data supplied by weather networks?" 
The usefulness of using historic $\mathrm{ET}_{\mathrm{c}}$ instead of real-time daily values of $\mathrm{ET}_{\mathrm{C}}$ supplied by weather networks was compared using 30-year average daily values of $\mathrm{ET}_{\mathrm{c}}$. The difference in applied irrigation when using the 30-year average $\mathrm{ET}_{\mathrm{c}}$ minus the "real-time" value of daily $\mathrm{ET}_{\mathrm{c}}$ provided by a weather network as a function of well capacity for the four years (low $\mathrm{ET}_{\mathrm{C}}, 1988$, moderate $\mathrm{ET}_{\mathrm{C}}, 1981$ and 2001, and high $\mathrm{ET}_{\mathrm{c}}, 1980$ ) at Plainview, TX, USA, is shown in Figure 6. The difference in irrigation amount varied among irrigation intervals and well capacities. For example, at the high well capacity $\left(2270 \mathrm{~L} \cdot \mathrm{min}^{-1}\right)$, using the long-term average $\mathrm{ET}_{\mathrm{c}}$ resulted in an over-irrigation of about $+50 \mathrm{~mm}$ in the low $\mathrm{ET}_{\mathrm{c}}$ year across all irrigation frequencies. Also, at the high well capacity using the 30-year average resulted in under-irrigation of about $-40 \mathrm{~mm}$ in the high $\mathrm{ET}_{\mathrm{c}}$ year for the 5-day and 10-day irrigation intervals. The equivalent amount of under-irrigation for the 1-day irrigation interval was $-25 \mathrm{~mm}$ (Figure 6). For all other years, well capacities and irrigation intervals, the differences in irrigation amounts applied between the long-term (30-year) average and "real-time" were on average similar, i.e., $-1 \pm 6 \mathrm{~mm}$. A potential problem when using a 30-year average value of $\mathrm{ET}_{\mathrm{c}}$ is that in years when $\mathrm{ET}_{\mathrm{c}}$ is low, over-irrigation could occur, and similarly in years with high $\mathrm{ET}_{\mathrm{c}}$, under-irrigation could occur. The practical significance of this bias would have to be viewed in light of the possible value of implementing $\mathrm{ET}_{\mathrm{C}}$-based irrigation in a region where there is minimal support to implement a real-time $\mathrm{ET}_{\mathrm{c}}$ network. These results suggested that in the THP, the potential water savings from using a "real-time" value of $\mathrm{ET}_{\mathrm{c}}$ compared to the 30-year average are, for practical purposes, minimal. This result suggest that ETc based irrigation can reduce both over- and under-irrigation.

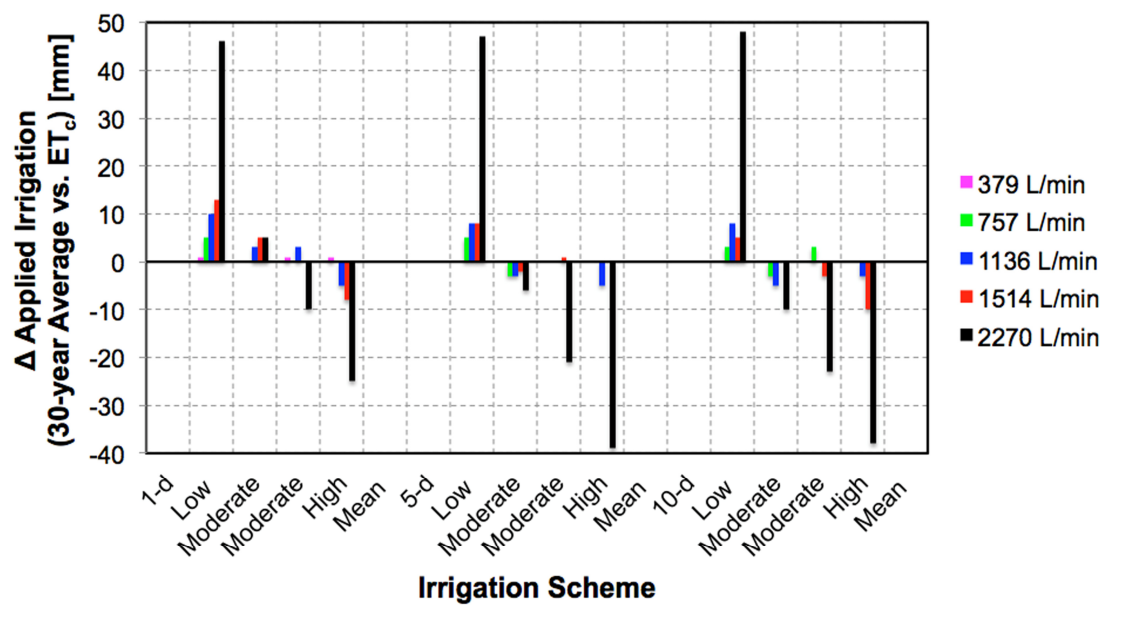

Figure 6. Difference of applied irrigation between the 30-year average and daily $\mathrm{ET}_{\mathrm{c}}(\mathrm{mm})$ as a function of irrigation scheme for the 1-day, 5-day and 10-day irrigation frequencies for Plainview, TX, USA. For each irrigation-frequency, the difference in applied irrigation between the 30-year average and daily $\mathrm{ET}_{\mathrm{C}}$ is plotted as a function of well capacity.

\section{Conclusions}

The results presented are best described in terms of an irrigation management approach based on a simple water balance, i.e., inputs and outputs. The primary input factor is the amount of irrigation water that can be applied over the growing season of the crop. This input is adjusted according to the rainfall received and amount of stored soil water. Given these inputs (irrigation, rain and stored soil water), how much water does the crop need and when should this water be applied? In our example, we selected and used a demand-response irrigation approach to answer these questions.

The results showed that when irrigation resources are sufficient for over-irrigation, a crop-ET approach provides the means to prevent over-irrigation, and the implementation of crop-ET approaches will generally result in reducing the amount of irrigation water applied. Further, when irrigation water is not limiting, differences in irrigation water applied when using a "real-time" daily $\mathrm{ET}_{\mathrm{c}}$ compared to a 30-year average $\mathrm{ET}_{\mathrm{c}}$ are minimal. This result suggested that it is reasonable to implement 
an $\mathrm{ET}_{\mathrm{c}}$-based irrigation using long-term values of $\mathrm{ET}_{\mathrm{c}}$, wherever "real-time" $\mathrm{ET}_{\mathrm{c}}$ is not available. In our example, for the THP using a 30-year average $\mathrm{ET}_{\mathrm{c}}$ for irrigation of cotton crop for a range of well capacities and irrigation schemes compared to a daily value of $\mathrm{ET}_{\mathrm{c}}$ from a weather network, resulted in similar values of irrigation water applied. Further, these differences are within the application "error" that can be achieved with sprinkler and drip irrigation systems. This finding suggests that even in the absence of a real-time weather network to generate $\mathrm{ET}_{\mathrm{c}}$ values, the use of a long-term historic $\mathrm{ET}_{\mathrm{c}}$ table by an irrigator is useful to reduce over-irrigation and perhaps to generate interest in the establishment of a real-time $\mathrm{ET}_{\mathrm{c}}$ network.

An initial question posed in our study was "why does it appear that irrigators in the THP are not making full use of $\mathrm{ET}_{\mathrm{c}}$-based irrigation management?" Weather network $\mathrm{ET}_{\mathrm{c}}$-based systems were introduced to the study area in the mid-1990, when well capacities where in the $2270 \mathrm{~L} \cdot \mathrm{min}^{-1}$ range (Wagner, 2012). However, over the past two decades irrigation capacities have significantly declined, and irrigation goals have shifted from preventing over-irrigation to deficit irrigation. Our results showed that, when well capacities decline to $<2270 \mathrm{~L} \cdot \mathrm{min}^{-1}$, the usefulness of an $\mathrm{ET}_{\mathrm{C}}$-based irrigation management declines to the extent that the perceived value of the weather network becomes less apparent and perhaps effectively non-existent from the irrigator's perspective.

One additional explanation for the decline in the use of public ET networks is the possibility that producer's lack of participation may be a result of them using private on-farm weather stations to calculate ET. Advances in weather monitoring make this a real possibility and may indeed contribute to the possible loss of interest in public networks. In this instance, loss of participation could be seen as an indicator of the producer's perceived value of ET-based scheduling as opposed to a lack of interest. Such an analysis is beyond the scope of this paper but might be valuable in some instances.

What are the broader implications of these findings? The transition from an irrigation management designed to prevent over-irrigation to a deficit-irrigation approach is occurring in many irrigated regions. On the THP where this study was conducted, a combination of reduced well capacities and governmental regulation of water withdrawals have resulted in response limits on irrigation that may require the development of non- $\mathrm{ET}_{\mathrm{c}}$ based irrigation management.

It is perhaps worth asking, why did the producers simply reduce the irrigated area to accommodate the reduced water supply? Currently, in the THP, there is interest in approaches to reduce irrigated areas in an economically advantageous manner. During the early 2000's, the issue was possibly complicated by the introduction of cotton varieties with increased water productivity that to some extent offset lint yield losses due to declining irrigation. Finally, insurance issues associated with the shift from irrigated to rainfed may have created some obstacles to abandonment of irrigated area that were not based solely on agronomic considerations. Again, this transition is now occurring in the THP, and efforts to reestablish the regional ET network are underway.

Current research in the ET irrigation community is focused on improving the coverage of weather networks with improved methods to calculate crop ET [56,57]. In addition, there is great interest and parallel effort directed toward the development of improved crop coefficients, e.g., [58-60]. Regardless of these efforts, it is probable that improvements in ET delivery and crop coefficients will not be sufficient to overcome the limits on $\mathrm{ET}_{\mathrm{c}}$-based irrigation management that result from declining water resources. Our results suggest that the inclusion of an irrigation management analysis based on a demand-response concept may prove useful to assess the utility of irrigation management schemes in general and with regard to research aimed toward improving or refining a given approach. When an $\mathrm{ET}_{\mathrm{c}}$-based irrigation management is to be implemented/refined, it might be helpful to ask the question; how will this improvement/refinement affect how the irrigator will respond to an irrigation demand? While increasingly local and accurate demand values may be obtainable, their value to the irrigator may be ultimately inconsequential. 
Acknowledgments: This research was supported in part by the Ogallala Aquifer Program, a consortium between USDA-Agricultural Research Service, Kansas State University, Texas A\&M AgriLife Research, Texas A\&M AgriLife Extension Service, Texas Tech University, and West Texas A\&M University.

Author Contributions: Both authors equally contributed to data analysis and the writing of the manuscript. James Mahan was responsible for the initial idea of questioning the value of weather networks for water management in areas where water resources are declining.

Conflicts of Interest: The authors declare no conflict of interest. Mention of trade names or commercial products in this publication is solely for the purpose of providing specific information and does not imply recommendation or endorsement by the U.S. Department of Agriculture. USDA is an equal opportunity provider and employer.

\section{Abbreviations}

$\begin{array}{ll}\text { CV } & \text { coefficient of variation } \\ \text { DOY } & \begin{array}{l}\text { day of year } \\ \text { crop evapotranspiration }\left(\mathrm{mm} \cdot \text { day }^{-1}\right)\end{array} \\ \mathrm{ET} & \text { cotton ET }\left(\mathrm{mm} \cdot \text { day }^{-1}\right) \\ \mathrm{ET}_{\mathrm{c}} & \text { standardized reference ET }\left(\mathrm{mm} \cdot \mathrm{day}^{-1}\right) \\ \mathrm{ET}_{\mathrm{Sz}} & \mathrm{ET}_{\mathrm{sz}} \text { for a short crop }\left(\mathrm{mm} \cdot \mathrm{day}^{-1}\right) \\ \mathrm{ET}_{\mathrm{os}} & \mathrm{ET}_{\mathrm{sz}} \text { for a tall crop }\left(\mathrm{mm} \cdot \mathrm{day}^{-1}\right) \\ \mathrm{ET}_{\mathrm{rs}} & \text { crop coefficient } \\ \mathrm{K}_{\mathrm{c}} & \text { low energy precision application } \\ \mathrm{LEPA} & \text { standard error } \\ \text { SE } & \text { Texas High Plains } \\ \text { THP } & \end{array}$

\section{References}

1. Hecht, A.D. Drought in the Great Plains: History of societal response. J. Clim. Appl. Meteorol. 1983, 22, 51-56. [CrossRef]

2. Changnon, S.A.; Lamb, P.J.; Hubbard, K.G. Regional climate centers: New institutions for climate service and climate-impact research. Bull. Am. Meteorol. Soc. 1990, 71, 527-537. [CrossRef]

3. Meyer, S.J.; Hubbard, K.G. Nonfederal automated weather stations and networks in the United States and Canada: A preliminary survey. Bull. Am. Meteorol. Soc. 1992, 73, 449-457. [CrossRef]

4. Elliott, R.L.; Hubbard, K.G.; Brusberg, M.D.; Hattendorf, M.J.; Howell, T.A.; Marek, T.H.; Snyder, R.L. The role of automated weather networks in providing evapotranspiration estimates. In National Irrigation Symposium, Proceedings of the 4th Decennial Symposium, Phoenix, AZ, USA, 14-16 November 2000; pp. 243-250.

5. Howell, T.A.; Meek, D.W.; Phene, C.J.; Davis, K.R.; McCormick, R.L. Automated weather data collection for research on irrigation scheduling. Trans. ASAE 1984, 27, 386-391. [CrossRef]

6. Curry, R.B.; Klink, J.C.; Holman, J.R.; Elwell, D.L.; Sciarini, M.J. Current Ohio experience with an automated weather station network. Appl. Eng. Agric. 1988, 4, 150-155. [CrossRef]

7. Elwell, D.L.; Klink, J.C.; Holman, J.R.; Sciarini, M.J. Ongoing experience with Ohio's automatic weather station network. Appl. Eng. Agric. 1993, 9, 437-441. [CrossRef]

8. Hoogenboom, G. The Georgia automated environmental monitoring network. In Proceedings of the 1993 Georgia Water Resources Conference, Athens, GA, USA, 20-21 April 1993; Hatcher, K.J., Ed.; Institute of Natural Resources: Concord, CA, USA, 1993; pp. 398-402.

9. Brock, F.V.; Crawford, K.C.; Elliott, R.L.; Cupercus, G.W.; Stadler, S.J.; Johnson, H.L.; Eilts, M.D. The Oklahoma Mesonet: A technical overview. J. Atmos. Ocean. Technol. 1995, 12, 5-19. [CrossRef]

10. Schroeder, J.L.; Burgett, W.S.; Haynie, K.B.; Sonmez, I.; Swirka, G.D.; Doggett, A.L.; Lipe, J.W. The West Texas Mesonet: A technical overview. J. Atmos. Ocean. Technol. 2005, 22, 211-222. [CrossRef]

11. Pierce, F.J.; Elliott, T.V. Regional and on-farm wireless sensor networks for agricultural systems in eastern Washington. Comput. Electron. Agric. 2008, 61, 32-43. [CrossRef]

12. Stewart, J.I.; Hash, C.T. Impact of weather analysis on agricultural production and planning decisions for the semiarid areas of Kenya. J. Appl. Meteorol. 1982, 21, 477-494. [CrossRef]

13. Zhang, Y.; Leuning, R.; Chiew, F.H.S.; Wang, E.; Zhang, L.; Liu, C.; Sun, F.; Peel, M.C.; Shen, Y.; Jung, M. Decadal trends in evaporation from global energy and water balances. J. Hydrometeorol. 2012, 13, 379-391. [CrossRef] 
14. Vanderlinden, K.; Giráldez, J.V.; Meirvenne, M.V. Assessing reference evapotranspiration by the Hargreaves method in Southern Spain. J. Irrig. Drain. Eng. 2004, 130, 184-191. [CrossRef]

15. Arneson, E.P. Early irrigation in Texas. Southwest. Hist. Q. 1921, 25, 121-130.

16. Bloodworth, M.E.; Gillett, P.T. IRRIGATION-Handbook of Texas Online; Texas State Historical Association: Austin, TX, USA, 1984. Available online: http://www.tshaonline.org/handbook/online/articles/ahi01 (accessed on 20 June 2016).

17. Hutchins, W.A. The community acequia: Its origin and development. Southwest. Hist. Q. 1928, 31, $261-284$.

18. Green, D.E. Land of the Underground Rain: Irrigation on the Texas High Plains, 1910-1970; University of Texas Press: Austin, TX, USA, 1973; p. 326.

19. Musick, J.T.; Pringle, F.B.; Walker, J.J. Sprinkler and furrow irrigation trends: Texas High Plains. Appl. Eng. Agric. 1988, 4, 46-52. [CrossRef]

20. Opie, J. Ogallala - Water for a Dry Land, 2nd ed.; University of Nebraska Press: Lincoln, NE, USA, $2000 ;$ p. 475.

21. Colaizzi, P.D.; Gowda, P.H.; Marek, T.H.; Porter, D.O. Irrigation in the Texas High Plains: A brief history and potential reductions in demand. Irrig. Drain. 2009, 58, 257-274. [CrossRef]

22. Musick, J.T.; Pringle, F.B.; Harman, W.L.; Stewart, B.A. Long-term irrigation trends: Texas High Plains. Appl. Eng. Agric. 1990, 6, 717-724. [CrossRef]

23. Scanlon, B.R.; Faunt, C.C.; Longuevergne, L.; Reedy, R.C.; Alley, W.M.; McGuire, V.L.; McMahon, P.B. Groundwater depletion and sustainability of irrigation in the US High Plains and Central Valley. Proc. Natl. Acad. Sci. USA 2012, 109, 9320-9325. [CrossRef] [PubMed]

24. English, M.J.; Musick, J.T.; Murty, V.V.N. Deficit irrigation. In Management of Farm Irrigation Systems; Hoffman, G.J., Howell, T.A., Solomon, K.H., Eds.; American Society of Agricultural Engineers: Saint Joseph, MI, USA, 1990; pp. 631-663.

25. Fereres, E.; Soriano, M.A. Deficit irrigation for reducing agricultural water use. J. Exp. Bot. 2007, 58, 147-159. [CrossRef] [PubMed]

26. Lyle, W.M.; Bordovsky, J.P. Low energy precision application (LEPA) irrigation system. Trans. ASAE 1981, 24, 1241-1245. [CrossRef]

27. Lyle, W.M.; Bordovsky, J.P. LEPA irrigation system evaluation. Trans. ASAE 1983, 26, 776-781. [CrossRef]

28. Bordovsky, J.P.; Lyle, W.M.; Lascano, R.J.; Upchurch, D.R. Cotton irrigation management with LEPA systems. Trans. ASAE 1992, 35, 879-884. [CrossRef]

29. Lascano, R.J. A general system to measure and calculate daily crop water use. Agron. J. 2000, 92, 821-832. [CrossRef]

30. Camp, C.R. Subsurface drip irrigation: A review. Trans. ASABE 1998, 41, 1353-1367. [CrossRef]

31. Jensen, M.E. Water consumption by agricultural plants. In Water Deficits in Plant Growth; Kozlowski, T.T., Ed.; Academic Press: New York, NY, USA, 1968; Volume II, pp. 1-22.

32. Allen, R.G.; Pereira, L.S.; Raes, D.; Smith, M. FAO_Irrigation and Drainage Paper, No. 56, Crop Evapotranspiration; FAO_-Food and Agriculture Organization of the United Nations: Rome, Italy, 1998; p. 326.

33. Allen, R.G.; Walter, I.A.; Elliott, R.; Howell, T.A.; Itenfisu, D.; Jensen, M.E. The ASCE Standardized Reference Evapotranspiration Equation; ASCE-EWRI Task Committee Report; American Society of Civil Engineers: Reston, VA, USA, 2005.

34. Saturated Thickness 2004. Available online: http://www.depts.ttu.edu/geospatial/center/Ogallala/ MapSeries/PDFs/03_SatThickness_8x11.pdf (accessed on 25 August 2016).

35. Marek, T.; Howell, T.A.; New, L.; Bean, B.; Dusek, D.; Michels, G.J. Texas North Plains PET Network. In Proceedings of the International Conference Evapotranspiration and Irrigation Scheduling, San Antonio, TX, USA, 3-6 November 1996; Camp, C.R., Sadler, E.J., Yoder, R.E., Eds.; American Society of Agricultural Engineers: San Antonio, TX, USA, 1996; pp. 710-715.

36. Winkler, R.L.; Murphy, A.H.; Katz, R.W. The value of climate information: A decision-analytic approach. J. Climatol. 1983, 3, 187-197. [CrossRef]

37. Jagtap, S.S.; Jones, J.W.; Hildebrand, P.; Letson, D.; O’Brien, J.J.; Podesta, G.; Zierdend, D.; Zazueta, F. Responding to stakeholder's demands for climate information: From research to applications in Florida. Agric. Syst. 2002, 74, 415-430. [CrossRef]

38. Artikov, I.; Hoffman, S.J.; Lynne, G.D.; Pytlik Zillig, L.M.; Hu, Q.; Tomkins, A.J.; Hubbard, K.G.; Hayes, M.J.; Waltman, W. Understanding the influence of climate forecasts on farmer decisions as planned behavior. J. Appl. Meteorol. Clim. 2006, 45, 1202-1214. [CrossRef] 
39. Klockow, K.E.; McPherson, R.A.; Sutter, D.S. On the economic nature of crop production decisions using the Oklahoma mesonet. Weather Clim. Soc. 2010, 2, 224-236. [CrossRef]

40. Carlson, J.D. The importance of agricultural weather information: A Michigan survey. Bull. Am. Meteorol. Soc. 1989, 70, 366-380. [CrossRef]

41. Seeley, M.W. The future of serving agriculture with weather/climate information and forecasting: Some indications and observations. Agric. For. Meteorol. 1994, 69, 47-59. [CrossRef]

42. Bolson, J.; Broad, K. Early adoption of climate information: Lessons learned from south Florida water resource management. Weather Clim. Soc. 2013, 5, 266-281. [CrossRef]

43. Vining, K.C.; Pope, C.A., III; Dugas, W.A., Jr. Usefulness of weather information to Texas agricultural producers. Bull. Am. Meteorol. Soc. 1984, 12, 1316-1319. [CrossRef]

44. Kenkel, P.L.; Norris, P.E. Agricultural producers' willingness to pay for real-time mesoscale weather information. J. Agric. Resour. Econ. 1995, 20, 356-372.

45. Irmak, S.; Rees, J.M.; Zoubek, G.L.; Van DeWalle, B.S.; Rathje, W.R.; DeBuhr, R.; Leininger, D.; Siekman, D.D.; Schneider, J.W.; Christiansen, A.P. Nebraska Agricultural Water Management Demonstration Network (NAWMDN): Integrating research and extension/outreach. Appl. Eng. Agric. 2010, 26, 599-613. [CrossRef]

46. Mayer, P.; DeOreo, W.; Hayden, M.; Davis, R.; Caldwell, E.; Miller, T.; Bickel, P. Evaluation of California Weather-Based "Smart" Irrigation Controller Programs; Water Engineering and Management: Boulder, CO, USA, 2009.

47. Zilberman, D.; Dinar, A.; MacDougall, N.; Khanna, M.; Brown, C.; Castillo, F. Individual and Institutional Responses to Drought: The Case of California Agriculture; Working Paper; Department of Agricultural \& Resource Economics, University of California: Berkeley, CA, USA, 1995.

48. Farahani, H.J.; Howell, T.A.; Shuttleworth, W.J.; Bausch, W.C. Evapotranspiration: Progress in measurement and modeling in agriculture. Trans. ASABE 2007, 50, 1627-1638. [CrossRef]

49. Strzepek, K.; Boehlert, B. Competition for water for the food system. Philos. Trans. R. Soc. B 2010, 365, 2927-2940. [CrossRef] [PubMed]

50. LaRue, J.; Yonts, C.D. Irrigation water supply. In Irrigation, 6th ed.; Stetson, L.E., Mecham, B.Q., Eds.; Irrigation Association: Falls Church, VA, USA, 2011; pp. 173-214.

51. Sneed, R.E.; Allen, R.G. Hydraulics of irrigation systems. In Irrigation, 6th ed.; Stetson, L.E., Mecham, B.Q., Eds.; Irrigation Association: Falls Church, VA, USA, 2011; pp. 215-270.

52. Mauget, S.; Leiker, G. The Ogallala agro-climate tool. Comput. Electron. Agric. 2010, 74, 155-162. [CrossRef]

53. Mahan, J.R.; Young, A.W.; Payton, P. Deficit irrigation in a production setting: Canopy temperature as an adjunct to ET estimates. Irrig. Sci. 2011, 30, 127-137. [CrossRef]

54. Davis, J.C. Statistics and Data Analysis in Geology, 3rd ed.; John Wiley \& Sons, Inc.: New York, NY, USA, 2002; p. 638.

55. Wagner, K. Status and Trends of Irrigated Agriculture in Texas; Texas Water Resources Institute: College Station, TX, USA, 2012; p. 6.

56. Lascano, R.J.; Van Bavel, C.H.M. Explicit and recursive calculation of potential and actual evapotranspiration. Agron. J. 2007, 99, 585-590. [CrossRef]

57. Lascano, R.J.; Van Bavel, C.H.M.; Evett, S.R. A field test of recursive calculation of crop evapotranspiration. Trans. ASABE 2010, 53, 1117-1126. [CrossRef]

58. Orgaz, F.; Testi, L.; Villalobos, F.J.; Fereres, E. Water requirements of olive orchards-II: Determination of crop coefficients for irrigation scheduling. Irrig. Sci. 2006, 24, 77-84. [CrossRef]

59. Suleiman, A.A.; Tojo Soler, C.M.; Hoogenboom, G. Determining FAO-56 crop coefficients for peanut under different water stress levels. Irrig. Sci. 2013, 31, 169-178. [CrossRef]

60. Sánchez, J.M.; Lopez-Urrea, R.; Doña, C.; Caselles, V.; Gonzalez-Piqueras, J.; Niclòs, R. Modeling evapotranspiration in a spring wheat from thermal radiometry: Crop coefficients and $\mathrm{E} / \mathrm{T}$ partitioning. Irrig. Sci. 2015, 33, 399-410. [CrossRef]

(C) 2016 by the authors; licensee MDPI, Basel, Switzerland. This article is an open access article distributed under the terms and conditions of the Creative Commons Attribution (CC-BY) license (http:/ / creativecommons.org/licenses/by/4.0/). 